S. PELIN ÇALIŞKANELLi, Ph.D. ${ }^{1}$

(Corresponding author)

E-mail: pelin.caliskanelli@deu.edu.tr

FIGEN COŞKUN ATASEVER, M.Sc. ${ }^{2}$

E- mail: figen-1989@hotmail.com

SERHAN TANYEL, Ph.D. ${ }^{1}$

E- mail: serhan.tanyel@deu.edu.tr

${ }^{1}$ Dokuz Eylül University Engineering Faculty

Department of Civil Engineering, 35160 İzmir, Turkey

2 Kocaeli University, Baki Komsuoğlu Bulv. No:515,

41380 Umuttepe İzmit/Kocaeli, Turkey
Traffic in the Cities

Preliminary Communication

Submitted: 14 July 2016

Accepted: 15 Feb. 2017

\title{
START-UP LOST TIME AND ITS EFFECT ON SIGNALIZED INTERSECTIONS IN TURKEY
}

\begin{abstract}
Start-up lost time is an important parameter in performance of signalized intersections which may in turn depict the effect of behaviour of different drivers for different countries. In this study the parameters affecting the startup lost time in Turkey will be defined and a model will be established to present the relationship between start-up lost time, saturation flow as well as start response time with the behaviour of Turkish drivers. For this purpose, observations were carried out at eight intersections in Turkey. Analyses have shown that saturation headways decrease with the increase in time in start response since the drivers in the 2nd and higher rows of a queue have a longer time to get prepared to discharge. Results also indicated that start-up lost time increases rapidly as cycle time increases, and lower start-up lost time values can be observed in left or right turning lanes.
\end{abstract}

\section{KEY WORDS}

signalized intersections; start-up lost time; saturation headways;

\section{INTRODUCTION}

One of the parameters which may show the effect of behaviour of different drivers for different countries is "start-up lost time". Start-up lost time is defined as the additional time, in seconds, consumed by the first few vehicles in a queue at a signalized intersection above and beyond the saturation headway, because of the need to react to the initiation of the green phase and to accelerate [1]. HCM [2] recommends that the minimum discharge headway be calculated as the average of the headways for the fifth through last queued vehicles. This approach implies that the first four vehicles affect all of the start-up lost time (i.e., N : 4) and it indicates that start-up lost time is generally about $2.0 \mathrm{sec} /$ phase. There are many factors that affect the start-up lost time, some of which are listed below:
- Vehicle type and gradient;

- Pedestrians in the intersection;

- Perception/reaction time which varies from driver to driver;

- Psychological factors.

Minh and Sano [3] defined that start-up lost time is the time lost due to driver reactions and vehicle acceleration. The start-up lost time is estimated by the sum of the difference between the observed headway of each vehicle and saturated headway. A graphical presentation of start-up lost time is given in Figure 1.

Driver start response time, which is an important indicator of driving characteristics, is another key parameter in the calculation of effective green time and determination of start-up lost time at signalized intersections. In literature, different values are suggested by various researchers: In one of the earlier studies on start response time Messer and Fambro [4] stated that, times except for the vehicle in the first position of the queue "1.0 second" for drivers' response time is acceptable; however, for the drivers in the leading position of the queue an additional delay of 2.0 seconds should be considered.

Institute of Transportation Engineers [5] and Akçelik et al. [6] both suggested 1.0 second for start response

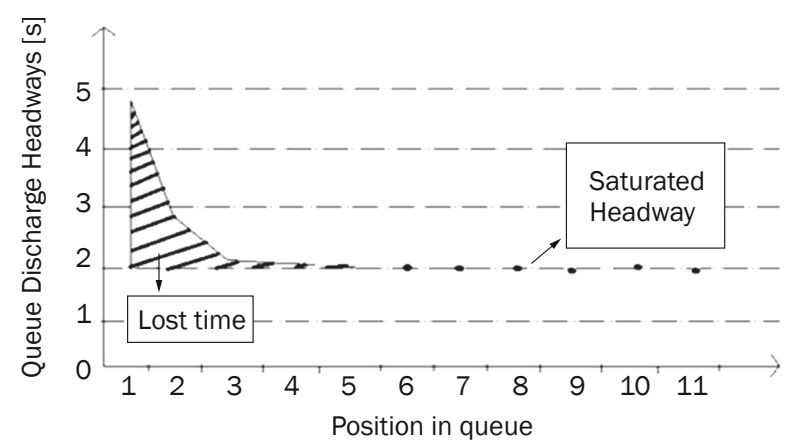

Figure 1 - Graphical representation of start-up lost time 
time. On the other hand, Bonneson [7] suggested 1.22 seconds; Li \& Prevedouros [8] suggested 1.76 and 1.42 seconds for through and left turning vehicles, respectively. In AIMSUN simulation program, start response time for leading vehicles in a queue is recommended at 1.35 [9] and Tong \& Hung [10] suggested 1.32 seconds for passenger cars and taxis. In AASHTO it is stated that this value may change between 1.0 2.5 seconds, considering different situations a driver may face [11]. In Turkey, Çalışkanelli \& Tanyel [12] found the mean values for through and left and right turning vehicles as $1.48 \mathrm{~s} ; 1.26 \mathrm{~s}$ and $1.39 \mathrm{~s}$, respectively. They also suggested an empirical function for the prediction of start response time of drivers in the leading position of a queue at a signalized intersection:

$$
t_{r}=-0.149 M N V-0.136 G N+0.020 C Y L
$$

where, $t_{r}$ is the start response time (seconds); MNV is the manoeuvre type (for through passing vehicles $M N V=0$, for right turning vehicles $M N V=1$ and for left turning vehicles MNV $=2$ ), GN is the gender of the driver ( 1 for male and 0 for female drivers) and $C Y L$ is the cycle time (seconds).

In literature, several researchers have emphasized that start response time has an important affect on saturation flow rate at signalized intersections [8, $10,12,13]$. The ideal saturation flow rate is defined in Highway Capacity Manual 2010 as the equivalent hourly rate at which previously queued vehicles can traverse an intersection approach under prevailing conditions, assuming that the green signal is available at all times and no lost times are experienced, in vehicles per hour or vehicles per hour per lane [1]. The ideal saturation flow value is considered to be affected by the traffic flow conditions of the intersection approach lane under examination, geometric features and environmental factors.

Saturation flow is another important parameter that needs to be investigated in the performance analysis of signalization systems. When the previous studies were examined, it was determined that the method based on headway was widely used in literature. One of the oldest studies on the headway value at signalized intersections is the study conducted by Greenshields et al. [14]. In the study, the researchers examined the average headway depending on the queuing position and they found that the average headway value decreased from the first vehicle to the fifth vehicle in the queue and remained almost stable after the sixth vehicle until the last vehicle in the queue.

However, several researchers have found that headway values decrease as the queue length increases. In one of the earlier studies, Carstens [15] examined the start-up delay and vehicle headway values for different types of vehicles and stated that there was a decrease in the headway values depending on the queuing position.
Lee and Chen [16] investigated the factors affecting the headways of the vehicles that passed straight through the intersection line and stated that the headway value was significantly affected by the queue length and the speed limit on the approach lane. Tong and Hung [10] analyzed the headway values obtained from signalized intersections using the method of artificial neural networks and determined that headway was affected by the queuing position, the type of subject or preceding vehicle and reaction times. Lin and Thomas [17] determined that the values of headway between the vehicles continued to decrease depending on the queuing position and showed that the headway value continued to decrease even after the fifteenth vehicle in the queue. Another study by Lu [18] showed that the headway values for small vehicles were smaller and the size of the vehicle in the first line of the queue had a significant impact on the headways of the other vehicles in the queue.

Regarding the determination of saturation flow value depending on the headways between the vehicles, it is seen that the headway values vary by time and different flow conditions even for the same region. The ideal saturation flow value is accepted as 1,800 $\mathrm{pc} / \mathrm{h} / \mathrm{In}$ (passenger cars per hour per lane) in HCM 1985 and as 1,900 pc/h/In in HCM 2000 [2, 19]. In HCM 2010, ideal saturation flow value is suggested as $1,900 \mathrm{pc} / \mathrm{h} / \mathrm{In}$ for metropolitan areas with population greater than 250,000 and as $1,750 \mathrm{pc} / \mathrm{h} / \mathrm{In}$ for other areas [1]. Furthermore, differences in saturation flow values are found in eastern and western countries owing to the differences in driver behaviours and flow characteristics [20]. It is considered that the differences in driver behaviours in Turkey, located at the intersection of the Asian and European continents, will also be reflected on the headway between vehicles and on the saturation flow values. There are very limited studies for Turkish drivers concerning the saturation flow value used in the analysis of signalized intersections.

Thus, Çalışkanelli [21] has found that, if the vehicles waiting in the queue were considered based on their positions, no statistically significant difference could be determined in the headway averages of the vehicles waiting at the 2 nd or higher queue positions. In other words, the vehicles in the queue at the signalized intersections under examination achieved the saturated headway state as the vehicles in the $2^{\text {nd }}$ line. In this case, it might be stated that the headways obtained from the intersections did not display the generally observed clear tendency to decrease.

From above it is obvious that saturation headway, start-up lost time and start response time are significant parameters in determination of intersection performance at signalized intersection systems which are especially located in urban road network. Akçelik et al. [6] defined the relationship between saturation headway, start-up lost time and start response time of the leading vehicle in the queue as follows: 
$h_{s}=t_{r}+d_{a}-t_{s}$

where $t_{r}$ is the start-response time of the leading vehicle in the queue (seconds), $d_{a}$ is the acceleration delay (seconds) and $t_{\mathrm{s}}$ is the start-up lost time (seconds). Depending on the saturated headway, the saturation flow value can be computed as:

$S=\frac{3600}{h_{s}}$

where $S$ is the saturation flow (vehicles/hour) and $h_{s}$ is the average saturated headway (seconds). From the above it is clear that all three parameters are highly related with each other.

In this study the parameters affecting the start-up lost time in Turkey will be defined and a model will be established to present the relationship between startup lost time, saturation flow as well as start response time with the behaviour of Turkish drivers. The paper is organized as follows: First the observation sites and observation methods are introduced. Then, analysis on queue discharge headways and start-up lost times is presented. In the final section, the relationship between start-up lost time, saturation flow and start response time is discussed.

\section{OBSERVATION STUDIES}

Observations are made at eight selected intersections in Turkey. Six of these intersections are located in Izmir, one is located in Bursa and the last one is located in istanbul. All intersections are located on the main arterials of Izmir, Bursa and Istanbul with relatively high traffic flows. They are also chosen because of convenience of video recordings and field measurements. Detailed information about the geometric features of these intersections is presented in Table 1. The general specifications of these intersections can be summarized as follows:

- Lane widths of lanes differ between 3.0 4.0 m;

- The longitudinal grade values in the approach lanes of the intersections are below 1\%;

- No parking or bus stops exist near the observed approaches;

Table 1 - Some geometric properties of observed intersections

\begin{tabular}{|c|c|c|c|c|c|c|c|c|c|}
\hline \multirow{2}{*}{ Intersection } & \multirow{2}{*}{ Observed approach } & \multicolumn{3}{|c|}{$\begin{array}{c}\text { Number of entrance } \\
\text { lanes }\end{array}$} & \multirow{2}{*}{$\begin{array}{c}\text { Width of } \\
\text { entrance } \\
\text { lane } \\
{[\mathrm{m} / \mathrm{ln}]}\end{array}$} & \multirow{2}{*}{$\begin{array}{l}\text { Num- } \\
\text { ber of } \\
\text { exit } \\
\text { lanes }\end{array}$} & \multirow{2}{*}{$\begin{array}{c}\text { Width of } \\
\text { exit lane } \\
\text { [m/ln] }\end{array}$} & \multirow{2}{*}{$\begin{array}{l}\text { Width } \\
\text { of } \\
\text { median } \\
{[\mathrm{m}]}\end{array}$} & \multirow{2}{*}{$\begin{array}{l}\text { Turning } \\
\text { lane }\end{array}$} \\
\hline & & LN & $\mathrm{T}$ & RT & & & & & \\
\hline \multirow{3}{*}{ Lunapark Int. } & $\begin{array}{l}\text { Girne Blv.d } \\
\text { (South Bound Appr.) }\end{array}$ & 1 & 1 & 1 & 3.30 & 2 & 3.50 & 2.50 & $\begin{array}{l}\mathrm{LT} \\
(60 \mathrm{~m})\end{array}$ \\
\hline & $\begin{array}{l}\text { Girne Blvd. } \\
\text { (North Bound Appr.) }\end{array}$ & 1 & 1 & 1 & 3.40 & 2 & 3.50 & 3.50 & $\begin{array}{c}\mathrm{RT} \\
(30 \mathrm{~m})\end{array}$ \\
\hline & $\begin{array}{l}\text { Atatürk Blv. } \\
\text { (West Bound Appr.) }\end{array}$ & 1 & - & 1 & 3.50 & 2 & 4.50 & 2.20 & - \\
\hline \multirow{2}{*}{$\begin{array}{l}\text { Balçova Çağdaş } \\
\text { Taksi Int. (İzmir) }\end{array}$} & $\begin{array}{l}\text { Mithat Paşa St. } \\
\text { (West Bound Appr.) }\end{array}$ & 1 & 1 & 1 & 3.70 & 3 & 3.30 & 25.00 & - \\
\hline & $\begin{array}{l}\text { Mithat Paşa St. } \\
\text { (East Bound Appr.) }\end{array}$ & 1 & 1 & 1 & 3.00 & 3 & 3.30 & 25.00 & - \\
\hline $\begin{array}{l}\text { Çankaya Int. } \\
\text { (İzmir) }\end{array}$ & $\begin{array}{l}\text { Gazi Osman Paşa Blvd } \\
\text { (Northeast Bound Appr.) }\end{array}$ & 1 & 1 & 1 & 3.60 & 2 & 3.00 & 2.40 & - \\
\hline $\begin{array}{l}\text { Altinşehir Int. } \\
\text { (İstambul) }\end{array}$ & $\begin{array}{l}03 \text { North St. } \\
\text { (Southwest Bound Appr.) }\end{array}$ & - & 1 & 1 & 3.25 & 2 & 4.00 & 5.00 & - \\
\hline $\begin{array}{l}\text { Atatürk Anadolu } \\
\text { Liseisi Int. (Bursa) }\end{array}$ & $\begin{array}{l}\text { Stadyum St. } \\
\text { (South Bound Appr.) }\end{array}$ & - & 1 & 1 & 3.25 & 2 & 3.50 & 5.00 & - \\
\hline \multirow{2}{*}{$\begin{array}{l}\text { Cin Deresi Int. } \\
\text { (İzmir) }\end{array}$} & $\begin{array}{l}\text { Mithat Paşa St. } \\
\text { (West Bound Appr.) }\end{array}$ & 1 & 2 & - & 3.20 & 3 & 3.80 & 1.80 & $\begin{array}{c}\mathrm{LT} \\
(50 \mathrm{~m})\end{array}$ \\
\hline & $\begin{array}{l}\text { Mithat Paşa St. } \\
\text { (East Bound Appr.) }\end{array}$ & - & 1 & 1 & 3.20 & 3 & 3.00 & 1.80 & - \\
\hline \multirow{2}{*}{$\begin{array}{l}\text { Vali Konaği Int. } \\
\text { (İzmir) }\end{array}$} & $\begin{array}{l}\text { Mustafa Kemal Sahil Blvd. } \\
\text { (Southwest Bound Appr.) }\end{array}$ & 1 & 3 & - & 3.20 & 3 & 3.90 & 11.50 & $\begin{array}{c}\mathrm{LT} \\
(500 \mathrm{~m})\end{array}$ \\
\hline & $\begin{array}{l}\text { Mustafa Kemal Sahil Blvd. } \\
\text { (Northeast Bound Appr.) }\end{array}$ & - & 3 & - & 4.00 & 3 & 4.00 & 11.50 & - \\
\hline $\begin{array}{l}\text { Yanuslar Int. } \\
\text { (İzmir) }\end{array}$ & $\begin{array}{l}\text { Girne Blvd. } \\
\text { (Southwest Bound Appr.) }\end{array}$ & - & 1 & 1 & 3.65 & 2 & 3.65 & 10.30 & - \\
\hline
\end{tabular}




\begin{tabular}{|c|c|c|c|c|c|c|c|c|c|c|c|c|c|c|c|c|c|c|c|c|c|c|c|c|c|c|c|c|c|c|c|c|}
\hline 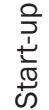 & $\begin{array}{l}\frac{c}{\sqrt[\varpi]{ }} \\
\stackrel{\mathbb{d}}{\Sigma}\end{array}$ & $\begin{array}{l}\widehat{0} \\
\dot{N}\end{array}$ & $\stackrel{\searrow}{\sim}$ & $\begin{array}{l}\hat{n} \\
\sim \\
\end{array}$ & 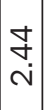 & $\stackrel{\Omega}{N}$ & Ö & $\begin{array}{l}\text { f } \\
\text { ने }\end{array}$ & $\begin{array}{l}\text { O } \\
\text { ஸ் }\end{array}$ & $\begin{array}{l}\text { ने } \\
\text { mं }\end{array}$ & $\begin{array}{l}\vec{A} \\
\text { m. }\end{array}$ & \begin{tabular}{l}
\multirow{N}{m}{} \\
$\dot{N}$
\end{tabular} & $\begin{array}{l}-1 \\
\infty \\
\dot{m}\end{array}$ & $\begin{array}{l}\text { வ } \\
\infty \\
\dot{N}\end{array}$ & $\begin{array}{l}m \\
\\
\dot{m}\end{array}$ & $\begin{array}{c}\stackrel{\bullet}{\sim} \\
\stackrel{\sim}{N}\end{array}$ & $\begin{array}{c}\mathfrak{N} \\
\stackrel{1}{*} \\
\sim \\
N\end{array}$ & ल) & $\stackrel{\circ}{\text { ㄱ. }}$ & $\begin{array}{l}\text { O) } \\
\text { ָu }\end{array}$ & 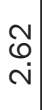 & $\begin{array}{c}\circ \\
\stackrel{-}{N} \\
\text { ণ }\end{array}$ & $\begin{array}{l}\text { ठ } \\
\text { ন }\end{array}$ & $\begin{array}{l}\infty \\
\sim \\
-\end{array}$ & $\stackrel{\text { ㄱ. }}{\stackrel{\text { N }}{\mathrm{N}}}$ & $\stackrel{\vec{r}}{\sim}$ & $\begin{array}{l}\stackrel{+}{m} \\
\text { N }\end{array}$ & $\begin{array}{l}\infty \\
\infty \\
-i\end{array}$ & $\begin{array}{l}\mathcal{N} \\
\stackrel{\sim}{N}\end{array}$ & \begin{tabular}{l}
$\bigcirc$ \\
\hdashline \\
$\dot{1}$
\end{tabular} & $\stackrel{\infty}{\underset{\sim}{\sim}}$ & $\hat{N}$ \\
\hline
\end{tabular}

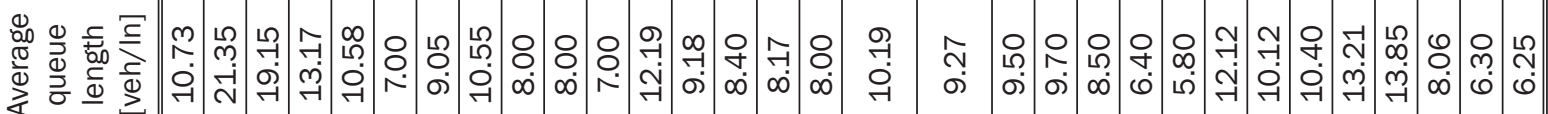

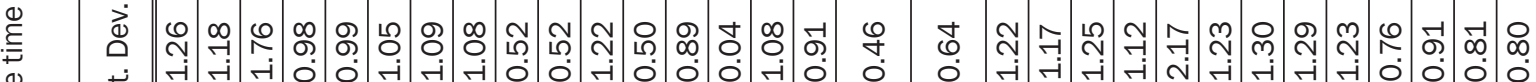
๓ मं

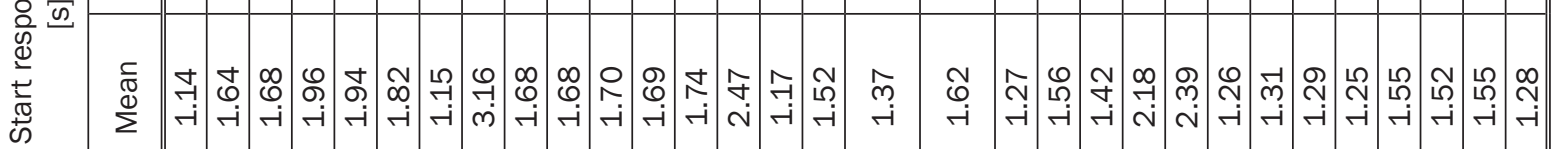

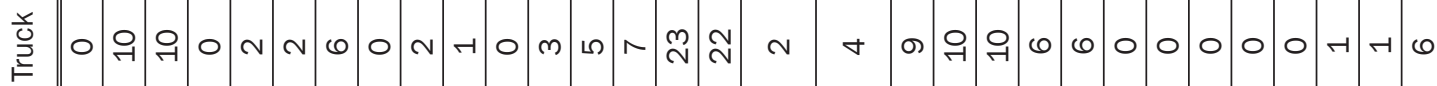
送 을

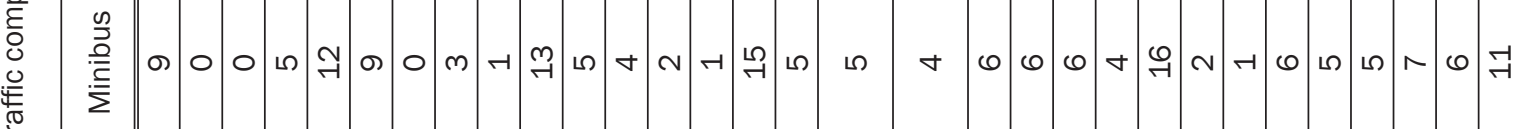
急

๘

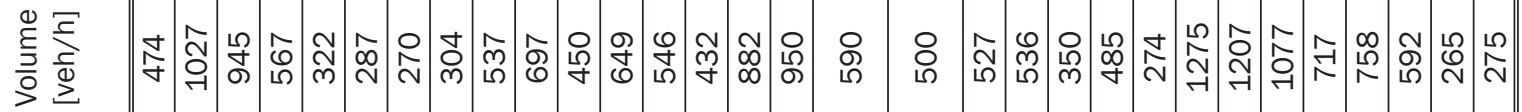

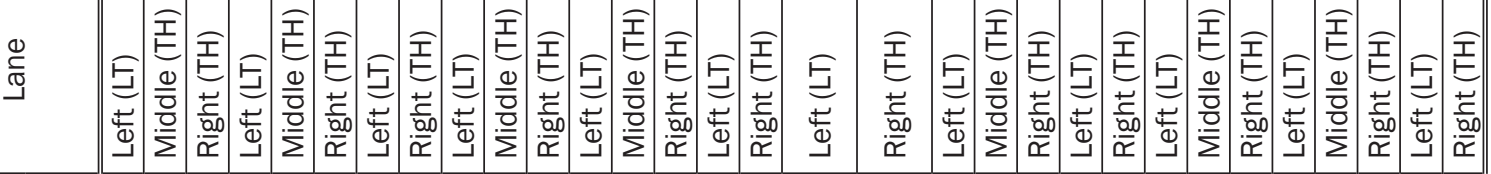

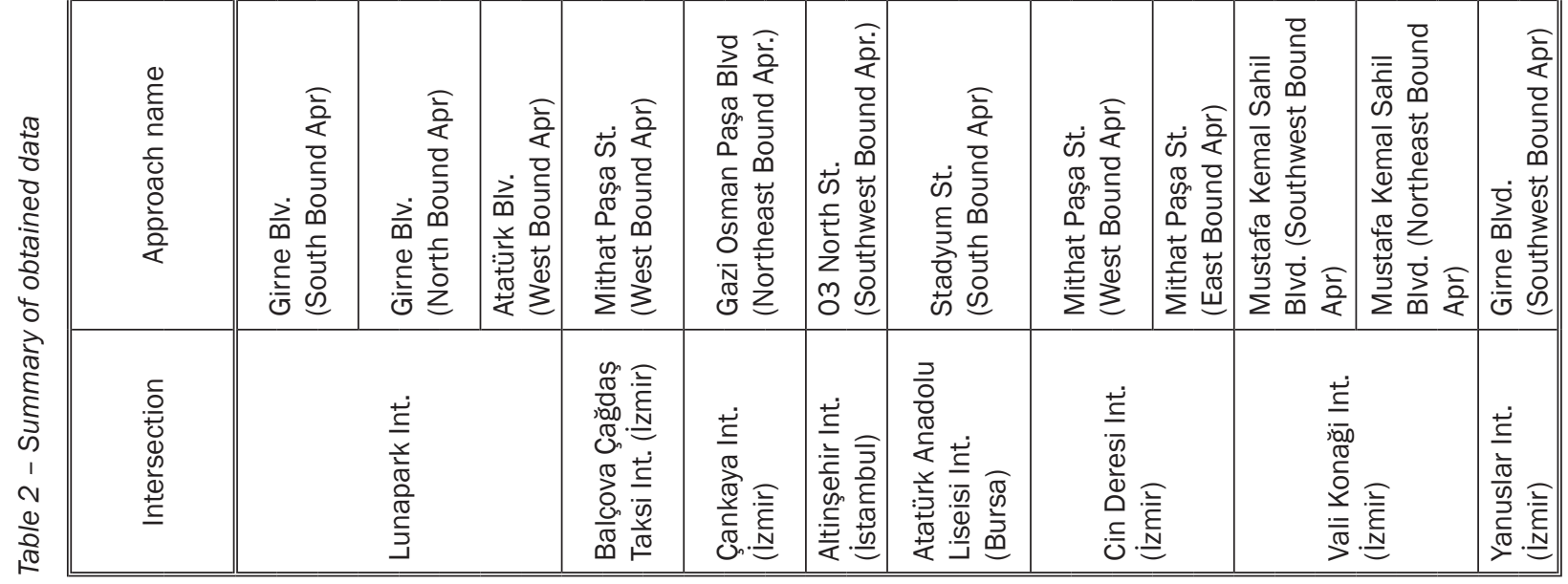


- No pedestrians and cyclists exist on a negligible level.

- Parking is not allowed on approach lanes especially in the peak hours observed.

Within the scope of the study, data were collected by means of video cameras which were placed on high buildings in order to capture the whole vehicle queues formed at the intersection lane. The recordings were generally performed by using two video cameras on weekdays when the weather conditions were favourable (with no rain), generally between 18:00 and 19:00 during peak traffic hours. Vehicle composition data are also collected from the recordings.

In the first stage, the queue lengths that occur during the red times and the queue discharge times of the approach lanes were determined. In the second stage of the study, the values of headway between the vehicles that began moving after a stop as the signal turned yellow were determined on the basis of the passages of the rear bumpers of the successive vehicles through the stop line. Unlike other vehicles, the headway value for the vehicles in the first line of the queue was measured by obtaining the time difference between the signal turning yellow from red and the passing of the rear bumper of the vehicle through the stop line.

Start response time can be defined as the average driver response time for the first vehicle to start moving at the start of the displayed green periods. For this purpose a video camera located near the stop line enabling both traffic signals and leading vehicle is utilized. An observer located in alignment with the signal and the leading vehicle recorded the start response time with a stop-watch The data obtained from both sources were crosschecked in order to obtain an accurate data set. The summary of obtained data is presented in Table 2.

\section{ANALYSIS ON START-UP LOST TIME}

In literature the start-up lost time is defined as the total time difference between the saturation headway and the first four headways [1]:

$t_{\mathrm{s}}=\sum_{i=1}^{4}\left(h_{i}-h_{\mathrm{s}}\right)$

In the equation $i$ is the position of the vehicle in a queue, $h_{i}$ is the queue discharge headway of $i$-th vehicle (seconds) and $h_{s}$ is the saturation headway (seconds). In this study, a total of 323 start-up lost time values were obtained from observed intersections (63 values from Bursa, 33 values from İstanbul; 32 values from Çankaya Int., İzmir; 25 values from Yunuslar Int., İzmir; 25 values from Cin Deresi Int., İzmir; 41 values from Çağdaş Taksi Int., İzmir; 58 values from Lunapark Int., İzmir and 46 values from Vali Konağı Int., İzmir are used in analysis). Descriptive statistics of start-up lost time values are presented in Table 3.
Table 3 - Descriptive statistics of start-up lost time values

\begin{tabular}{||c|c|c|c|c||}
\hline Average & $\begin{array}{c}\text { Std. } \\
\text { deviation }\end{array}$ & Median & $\begin{array}{c}\text { Minimum } \\
\text { value }\end{array}$ & $\begin{array}{c}\text { Maximum } \\
\text { value }\end{array}$ \\
\hline \hline 2.32 & 1.65 & 1.89 & 0.01 & 6.96 \\
\hline
\end{tabular}

In HCM 2010, start-up lost time value is suggested as 2.0 seconds [1]. From Table 3 it is clear that the average of observations is greater than 2.0 seconds. It is also clear that the observed start-up lost time values differ in a wide range. This also gives a relatively high standard deviation value.

In literature, only a limited number of studies were carried out for the distribution of start-up lost time values. One of the latest studies belongs to Tan et al. [22] where they suggested a distribution function for start-up lost time values. In this study, various statistical distributions were examined to define the appropriate statistical distribution model. The analysis showed that Weibull Distribution is the statistical model which can be used to represent start-up lost times at signalized intersection approaches (Anderson-Darling value is 0.628 and $P$ value is 0.102 for Weibull distribution). The probability distribution curves of observed values $f\left(t_{s}\right)$ and fitted Weibull distribution $g\left(t_{s}\right)$ are presented in Figure 2.

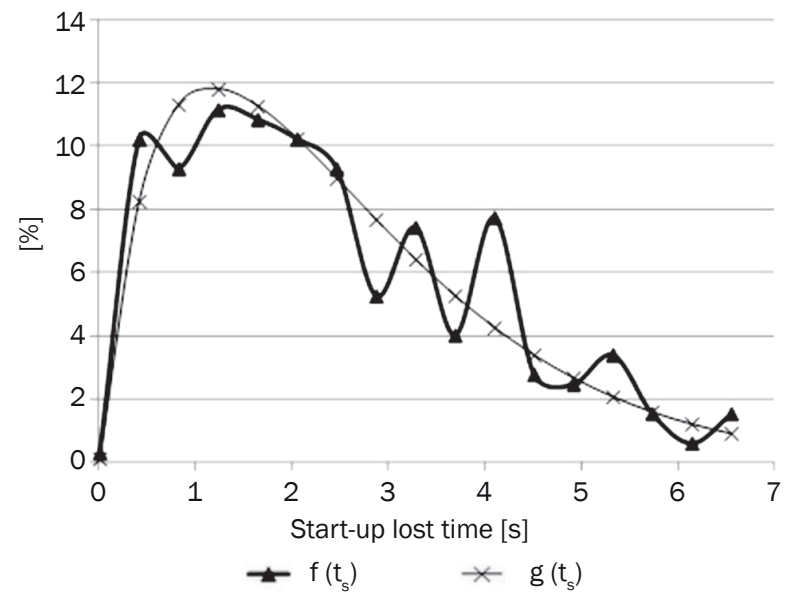

Figure 2 - Cumulative distribution curves of observed values $f\left(t_{s}\right)$ and Weibull predictions $g\left(t_{s}\right)$

The probability density function of Weibull distribution can be written as:

$g\left(t_{s}\right)=\left(\frac{\beta t_{s}^{\beta-1}}{\eta^{\beta}}\right) e^{\left[-\left(\frac{t_{s}}{\eta}\right)^{\beta}\right]}$

where $\eta$ and $\beta$ are scale and shape parameters of Weibull distribution, respectively. Weibull distribution is generally used as a lifetime distribution in reliability applications [23].

Weibull distribution is used to represent the breakdown probability in traffic flows on highways and expressways and in gap acceptance analysis at 
unsignalized intersections [24, 25]. Thus, start-up lost time can be assumed as one of the measures of traffic breakdown at signalized intersections.

In the study an attempt is made to identify the parameters affecting the start-up lost time value. Cycle time, green time, lane width, traffic composition (percentage of minibus, bus and trucks), left or right turning rate of vehicles and queue lengths were used as independent variables. Using the mentioned parameters, a regression analysis was performed. Results show that start-up lost time $\left(t_{s}\right)$ is affected by lane width $\left(W_{L}\right)$, bus percentage in the queue $\left(P_{\text {bus }}\right)$ and queue length $\left(L_{q}\right)$ (Equation 6). However, the result of regression analysis is rather weak and it can only be used for an initial approach to understand the physical nature of start-up lost time. In Figures 3-4, the effects of these parameters can be analyzed more clearly.

$$
t_{s}=8.00-1.94 W_{L}+3.31 P_{\text {bus }}+0.07 L_{q}
$$

As depicted in Figure 3 it can be observed that start-up lost time increases as more vehicles join the queue. Although this result conflicts with the study of $\mathrm{Li}$ and Prevedouros [8], it clearly shows that the first four vehicles in a queue move rather slowly and drivers tend to move faster and follow each other with smaller headways. On the other hand the start-up lost time decreases as the lane width increases. This is due to the drivers feeling safer and moving faster as the queue discharges.

Figure 4 represents the relationship between Queue Length - Bus percentage and Start-up Lost time. From the figure it is clear that start-up lost time value increases rapidly when the queue length exceeds 17 veh/lane and when the percentage of buses reaches 20 25\%. Buses need more time to accelerate in comparison to automobiles and eventually have major effect on the start-up lost time.

All parameters used in regression analysis are either related to geometric parameters or traffic management and flow characteristics of a signalized intersection approach. However, start-up lost time is strongly related to driver characteristics and environmental factors. One of the outstanding parameters which reflects driver characteristics is the start response time of leading drivers at a traffic signal.

Figure 5 presents the relationship between start response time and start-up lost time values obtained from the observations. It is obvious that start-up lost time is a function of start response time. When Equation 1 and the the equation presented in Figure 5 are used together, the effect of cycle time and manoeuvre type on start-up lost time can be predicted (Figure 6). From Figure 6 it is clear that start-up lost time increases rapidly as cycle time increases. This shows that longer cycle times distract the drivers' attention. Results also indicate that lower start-up lost time values can be observed on left or right turning lanes.

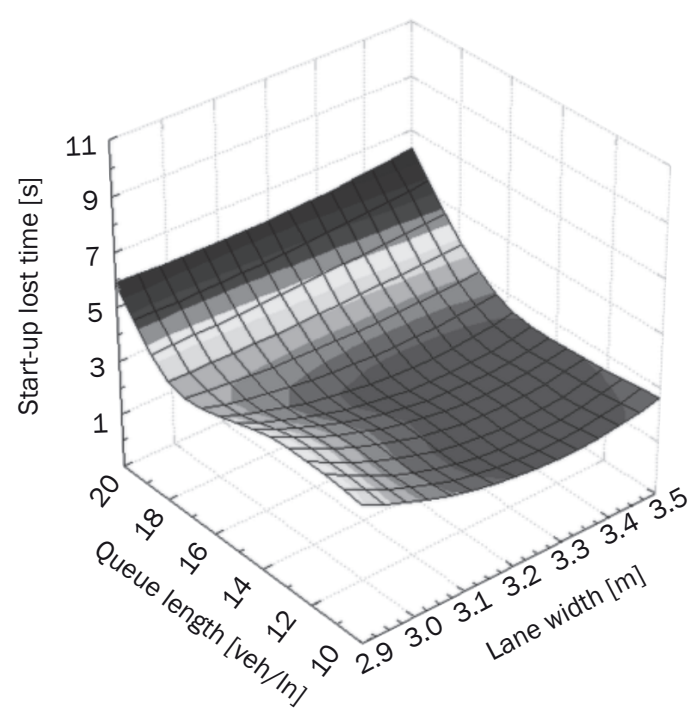

Figure 3 - Lane width - Queue length and Start-up lost time relationship

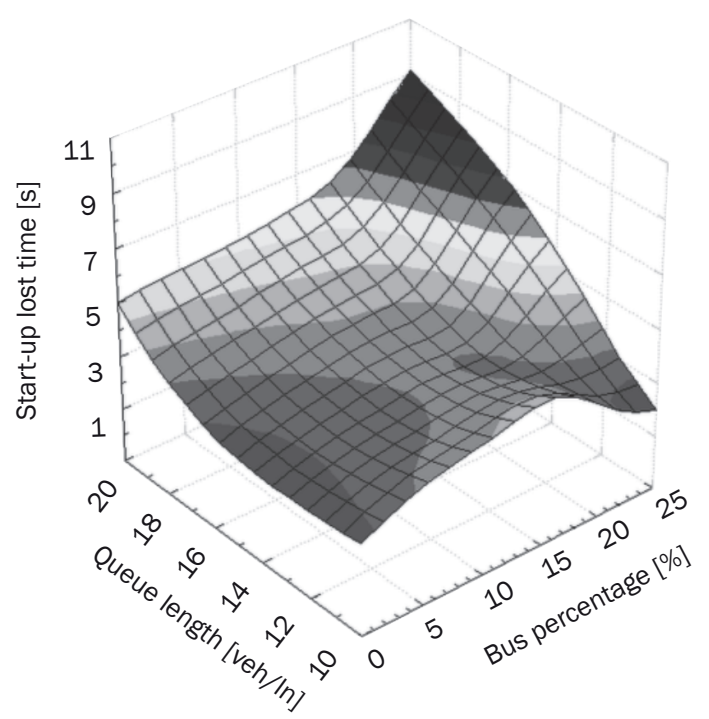

Figure 4 - Queue Length - Bus percentage and Start-up Lost time relationship

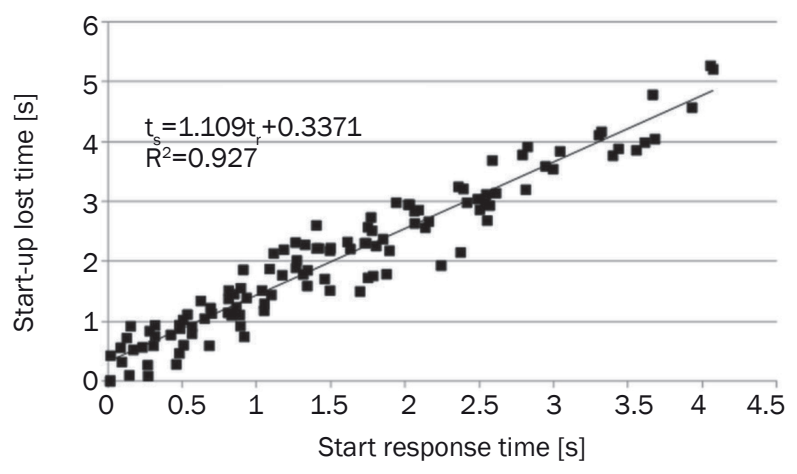

Figure 5 - Relationship between start response time and start-up lost values 


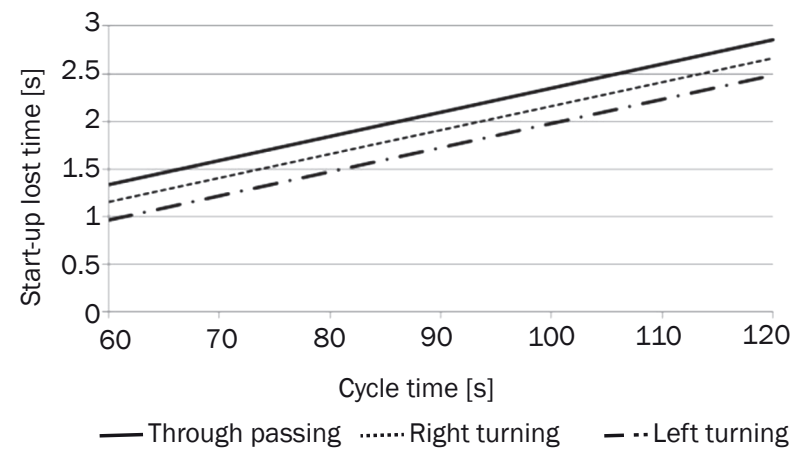

Figure 6 - The change of start-up lost time with respect to manoeuvre type and cycle time

\section{DISCUSSION ON SATURATION HEADWAY}

Li and Prevedouros (2002), suggested the following equation for prediction of start-up lost time:

$t_{s}=t_{r}+4\left(H_{a v f f}-h_{s}\right)$

In the equation $H_{\text {avff }}$ is the average queue discharge headways of first four vehicles in the queue of a signalized approach (seconds). This equation can be rewritten as:

$h_{s}=H_{\text {avff }}+\frac{t_{r}-t_{s}}{4}$

The relationship between start response time and start-up lost time is found in the previous section (Figure 5) as:

$t_{s}=0.337+1.11 t_{r}$

If Equation 9 is placed in Equation 8 then the following equation is obtained:

$h_{s}=H_{\text {avff }}-\frac{-\left(0.337+0.11 t_{r}\right)}{4}$

Equation 10 proves that saturation headway decreases with increasing start response time of drivers in the first line of the queue at a traffic signal. By using the same approach, Equation 2 can be rewritten as:

$h_{s}=d_{a}\left(0.337+0.11 t_{r}\right)$

Figure 7 shows the comparison of observed and predicted values which are obtained by using Equation 10 . When Figure 7 is examined carefully, it is clear that although the slope of the comparison equation is relatively close to " 1 ", $R^{2}$ value is found to be rather low.

To obtain a more suitable equation which reflects the relationship between saturation headway and $t_{r}$ and Havff values, a regression analysis is performed. The results of the regression analysis are shown in Table 4 and the obtained empirical function is given in Equation 12. The regression analysis shows a very strong relationship between saturation headway and $t_{r}$ and Havff $\left(\mathrm{R}^{2}=0.961\right)$. "t-stat" values of independent parameters of the model $\left(H_{\text {avff }}\right.$ and $\left.t_{r}\right)$ are much greater than " 2 " and $p$-values of both independent variables

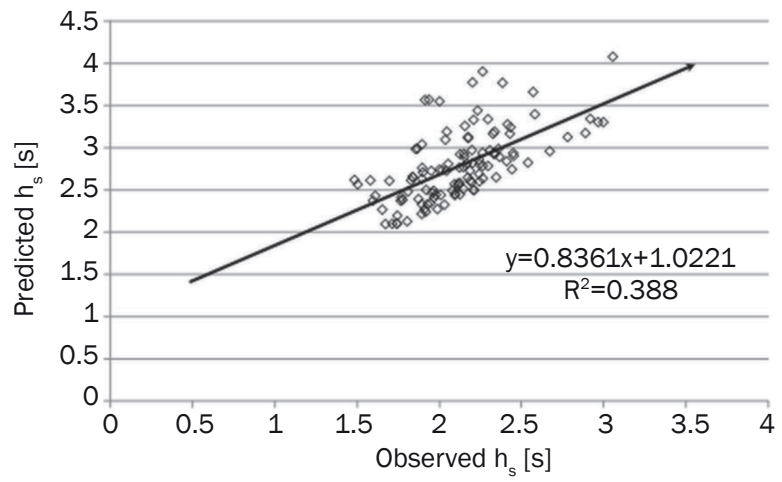

Figure 7 - Comparison of observed and predicted $h_{\mathrm{s}}$ values

Table 4 - Multiple regression statistics of saturation headway, start response time and average queue discharge headways of first four vehicles in the queue

\begin{tabular}{|l|c|c|c|c||}
\hline & $\beta$ & Std. error & t-stat & p-value \\
\hline \hline Constant & -0.110 & 0.045 & 2.431 & 0.017 \\
\hline$H_{\text {avff }}$ & 0.929 & 0.0177 & 52.441 & $1.193 \times 10^{-81}$ \\
\hline$t_{r}$ & -0.314 & 0.007 & 42.962 & $2.976 \times 10^{-72}$ \\
\hline
\end{tabular}

Note: $R^{2}=0.961 ; S S=10.56 ; M S=5.28 ; F$-value $=1427.81$;

F-prob $=1.99 \times 10^{-81}$

are very close to zero. This shows that they are both significant in defining hs. Thus, the results are similar to Equation 10, and the sign of $t_{r}$ is negative. To evaluate the regression by analyzing the sum of squares of residual errors (SSE), F-test is also applied and its result is given below the table. It is clear that the result of F-test is satisfactory.

$h_{s}=0.110+0.929 H_{\text {avff }}-0.314 t_{r}$

In Figure 8, a comparison of Equations 10 and 12 are presented $\left(t_{r}\right.$ value is calculated from Equation 1 by assuming all vehicles are through passing and total cycle time is 90 seconds). From the figure it is clear that empirical function gives lower $h_{s}$ values. In other words, Equation 10 may lead an engineer to underestimate the capacity and overdesign a signalized intersection approach.

In Figure 9, the effect of start response time and $H_{\text {avff }}$ on saturation flow is shown. As stated above, as

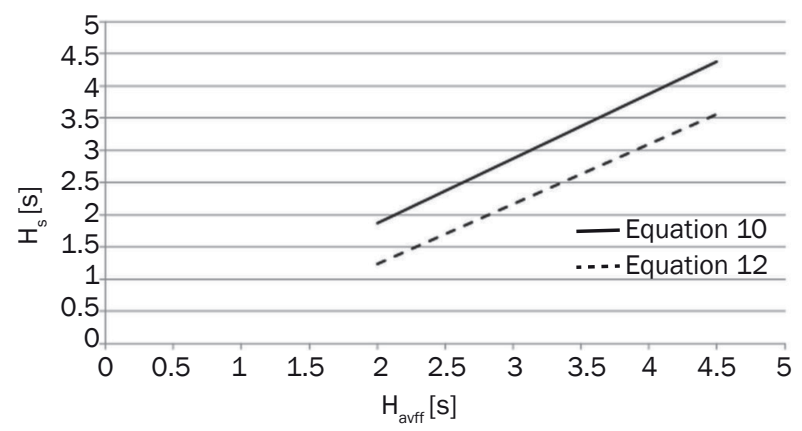

Figure 8 - Comparison of saturation headway values obtained from proposed models 
the $t_{r}$ value increases, saturation flow also increases. On the other hand, there is an inverse relation between $H_{\text {avff }}$ and the saturation flow.

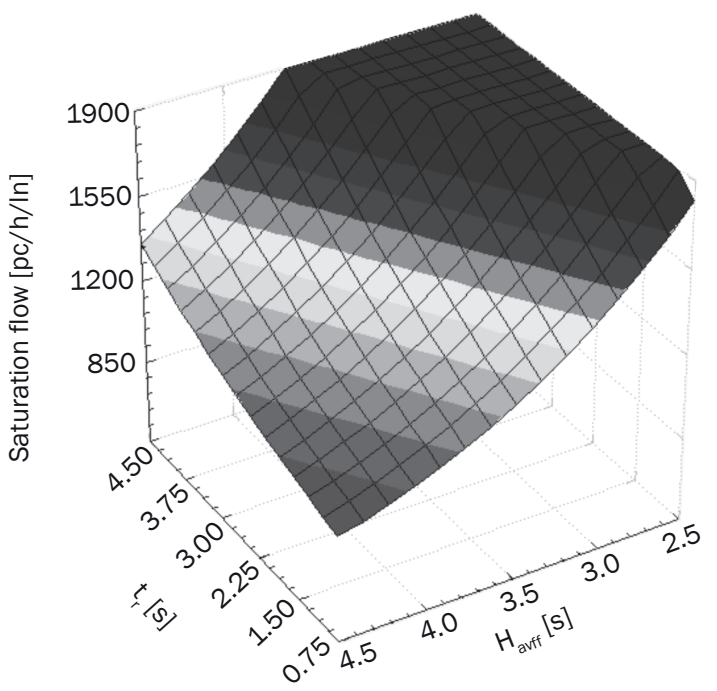

Figure 9 - Graphical presentation of the effect of start response time and Havff on saturation flow

\section{CONCLUSION}

This study tries to identify the relationship between queue discharge headways, start response time and start-up lost time. In the light of detailed analysis, the following results can be reached:

- Weibull Distribution is the statistical model which can be used to represent start-up lost times at signalized intersection approaches. As Weibull distribution is generally used as a lifetime distribution in reliability applications; it can be said that start-up lost time can also be assumed as one of the measures of traffic breakdown at signalized intersections.

- Lane width and bus percentage are other two parameters which are related to start-up lost time. Start-up lost time decreases as the lane width increases. This is because drivers feel safer and move faster as the queue discharges. On the other hand, start-up lost time value increases rapidly when queue length exceeds $17 \mathrm{veh} / \mathrm{In}$ and percentage of buses reaches 20 25\%. The results also indicate that start-up lost time increases as cycle time increases and lower start-up lost time values can be observed in left or right turning lanes.

- Start-up lost time is highly related to start response time of the leading driver in the queue. By using this approach, saturation headway value can be calculated by using the average queue discharge headways of the first four vehicles in a queue and start response time (Equations 10 and 12).

- Another important result of the study is the decrease in saturation headways while the start response time increases. This is because the drivers in the $2^{\text {nd }}$ and higher rows of a queue have longer time to get prepared to discharge.

The results of this study may be used in the capacity and performance analyses of signalized intersections. For further studies, the researchers may try to define better models for start-up lost time and start response time as they are found to be two important parameters which can be used in understanding the effect of human factor in traffic flow.

\section{ACKNOWLEDGEMENT}

This study includes the findings obtained from the research project entitled "Investigation of Effect of Driver Behavior on the Capacity and Performance of Urban Intersection and Arterials" supported by The Scientific and Technological Research Council of Turkey (TÜBITAK, Project No. 110M677). The authors appreciate TÜBITAK for project support.

\section{Dr. S. PELIN ÇALIŞKANELLi ${ }^{1}$}

E-posta: pelin.caliskanelli@deu.edu.tr Inş.Y.Müh. FiGEN COŞKUN ATASEVER ${ }^{2}$

E-posta: figen-1989@hotmail.com

Dr. SERHAN TANYEL ${ }^{1}$

E-posta: serhan.tanyel@deu.edu.tr

1 Dokuz Eylül Üniversitesi Mühendislik Fakültesi İnşaat Mühendisliği Bölümü, 35160 İzmir, Türkiye

2 Kocaeli Üniversitesi, Baki Komsuoğlu Bulv. No:515, 41380 Umuttepe İzmit/Kocaeli, Türkiye

\section{BAŞLANGIÇ ZAMAN VE TÜRKIYE'DEKI SINYALIZE KAVSSAKLAR ÜZERINDEKI ETKISI}

\section{ÖZET}

Başlangıç kayıp zaman, farklı ülkelerdeki farklı sürücü davranışlarının sinyalize kavşak performansı üzerindeki etkilerini de yansıtabilen önemli bir parametredir. Bu çalışmada, başlangıç kayıp zamanı etkileyen parametreler tanımlanmış ve Türk sürücü davranışları açısından başlangıç kayıp zaman, doygun akım ve başlangıç tepki süresi arasındaki ilişkiyi belirleyen için bir model oluşturulmuştur. Bu amaçla Türkiye'deki 8 kavşakta gözlem yapılmıştır. Analizler kuyrukta 2. Sıradan itibaren bekleyen sürücülerin harekete geçmek için daha fazla süreye sahip olmaları sebebiyle başlangıç tepki süresi uzadıkça doygun takip aralık değerlerinin düştüğünü göstermiştir. Sonuçlar aynı zamanda devre süresi uzadıkça başlangıç kayıp zamanının arttığını ve sağ ya da sol şeritte daha düşük başlangıç kayıp zaman değerlerinin gözlemlenebileceğini ortaya koymuştur.

\section{ANAHTAR KELIMELER:}

Sinyalize kavşaklar; başlangıç kayıp zaman; doygun takip aralığl;

\section{REFERENCES}

[1] Transportation Research Board (TRB). Highway Capacity Manual. Washington, D.C.: Transportation Research 
Board, National Research Council; 2010.

[2] Transportation Research Board (TRB). Highway Capacity Manual. Washington, D.C.: Transportation Research Board, National Research Council; 1985.

[3] Minh CC, Sano K. Analysis of motorcycle effects to saturation flow rate at signalized intersection in developing countries. Journal of Eastern Asia Society for Transportation Studies. 2003;5:1211-1222.

[4] Messer CJ, Fambro DB. Effects of Signal Phasing and Lengths of Left-Turn Bay on Capacity. 56th Annual Meeting of the Transportation Research Board. Transportation Research Board of National Academies Transportation Research Record. 1977;644:95-101.

[5] Institute of Transportation Engineers. Determination of Vehicle Signal Change and Clearance Intervals. Publication IR-073. Washington, D.C.; 1994.

[6] Akçelik R, Besley M, Roper R. Fundemantal relationships for traffic flows at signalized intersections. ARRB Transportation Research Ltd., Research Report ARR 340; 1999.

[7] Bonneson JA. Modelling queued driver behavior at signalized junctions, Transportation Research Board of National Academies Transportation Research Record. 1992;1365:99-107.

[8] Li H, Prevedouros PD. Detailed observations of saturation headways and start-up lost time. Journal of Transportation Research Board. 2002;1802: 44-53.

[9] TSS-Transportation Simulation Systems. Aimsun 6.1 User Manual; 2005-2010.

[10] Tong HY, Hung WT. Neural network modelling of vehicle discharge headway at signalized intersection: model descriptions and results. Transportation Research Part A: Policy and Practice. 2002;36(1):17-40.

[11] Roess PR, Prassas ES, McShane WR. Traffic Engineering. 3rd ed. New Jersey, USA: Pearson Prentice Hall; 2004.

[12] Çalışkanelli SP, Tanyel S. Investigating the Driver Response Time at Signalized Intersections. Transport. 2016. doi: 10.3846/16484142.2016.1250106

[13] Long G. Start-up delays of queued vehicles. Journal of
Transportation Research Board. 2005;1934:125-131.

[14] Greenshields BD, Schapiro D, Ericksen EL. Traffic performance at urban intersections. Saugatuck, Conn.: Eno Foundation for Highway Traffic Control; 1947.

[15] Carstens RL. Some traffic parameters at signalized intersection. Traffic Engineering. 1971;41(11):33-36.

[16] Lee J, Chen RL. Entering headway at signalized intersections in a small metropolitan area. Transportation Research Record. 1986;1572:24-32.

[17] Lin FB, Thomas DR. Headway compression during queue discharge at signalized intersection. Journal of the Transportation Research Board. 2005;1920:8185.

[18] Lu YJ. A study of left-turning maneuver time for signalized intersections. ITE Journal. 1984;58(10):42-47.

[19] Transportation Research Board (TRB). Highway Capacity Manual. Washington, D.C.: Transportation Research Board, National Research Council; 2000.

[20] Nıttymaki J, Pursula M. Saturation flows at signal-group-controlled traffic signsals. Transportation Research Record; 1997. Vol. 1572. doi: 10.3141/1572-04

[21] Çalışkanelli SP. Sinyalizasyon Sistemlerinden Ayrılan Araçların Takip Aralığı Dağılımının İncelenmesi [PhD thesis]. İzmir: Dokuz Eylül University; 2010. Turkish

[22] Tan J, Li L, Li Z, Zhang Y. Distribution models for start-up lost time and effective departure flow rate. Transportation Research Part A: Policy and Practice. 2013;51:1-11.

[23] Evans M, Hastings N, Peacock B. Statistical Distributions. 3rd ed. New York, USA: John Wiley \& Sons Inc.; 2000.

[24] Wu N. Stochastic Model for Reliability Analysis in Freeway Networks. Procedia - Social and Behavioral Sciences. 2013;96:2823-2834.

[25] Alhajyaseena WKM, Asanob M, Nakamurab H. Leftturn gap acceptance models considering pedestrian movement characteristics. Accident Analysis and Prevention. 2013;50:175-185. 